Article

\title{
Ionization of a covalent organic framework for catalyzing the cycloaddition reaction between epoxides and carbon dioxide
}

\author{
Yan Zhang a, Hui Hu b, Jia Ju a, Qianqian Yan b, Vasanthakumar Arumugam b, Xuechao Jing c,\#, \\ Huaqiang Cai ${ }^{\mathrm{a}, *}$, Yanan Gao ${ }^{\mathrm{b}}$ \\ a Institute of Chemical Materials, China Academy of Engineering Physics, Mianyang 621900, Sichuan, China \\ ${ }^{\mathrm{b}}$ Key Laboratory of Ministry of Education for Advanced Materials in Tropical Island Resources, Hainan University, Haikou 570228, Hainan, China \\ c Liaocheng Luxi Polycarbonate Co. Ltd, Liaocheng 252000, Shandong, China
}

A R T I C L E I N F O

Article history:

Received 29 June 2019

Accepted 25 July 2019

Published 5 March 2020

\section{Keywords:}

Covalent organic framework

Ionization

$\mathrm{CO}_{2}$

Cycloaddition

Heterogeneous catalyst

\begin{abstract}
A B S T R A C T
Covalent organic frameworks (COFs), with two dimensional (2D-) or three dimensional (3D-) structures, have accessible open channels or nanopores, with uniform sizes ranging from angstroms to nanometers and have emerged as an excellent and promising platform for designing catalysts or catalyst carriers. Herein, a 2D-COF grafted with a 1-alkyl-3-methylimidazolium-based ionic liquid (AMIMBr@ $\mathrm{H}_{2} \mathrm{P}-\mathrm{DHPh} \mathrm{COF}$ ) on the channel walls was synthesized and utilized as a highly efficient heterogeneous catalyst for the chemical fixation of $\mathrm{CO}_{2}$ via a reaction with epoxides under solvent-free and co-catalyst-free conditions. The as-synthesized AMIMBr@ $\mathrm{H}_{2} \mathrm{P}-\mathrm{DHPh}$ COF shows excellent catalytic activity in promoting the cycloaddition reactions between epoxide and $\mathrm{CO}_{2}$; the excellent catalytic activity was maintained for up to five cycles. Advantages like high porosity, functional versatility, easy modification of COFs, and high catalytic activity of ionic liquids, have been realized in a single material.
\end{abstract}

(c) 2020, Dalian Institute of Chemical Physics, Chinese Academy of Sciences. Published by Elsevier B.V. All rights reserved.

\section{Introduction}

Recently, considerable research has been focused on chemical transformations to useful chemicals using $\mathrm{CO}_{2}$ as a feedstock. This is because the accumulation of $\mathrm{CO}_{2}$ in the atmosphere is accelerating at a frightening pace and is considered the leading cause of the greenhouse effect over the past few decades [1-4]. Among these transformations, the synthesis of cyclic carbonates from epoxides and $\mathrm{CO}_{2}$ has attracted increasing attention due to their high efficiency in industrial processes [5-10]. For example, cyclic carbonates can be widely used as aprotic high-boiling polar solvents, electrolytes for lithium-ion batteries, precursors of polymeric materials, and fine chemical intermediates.
In the last decade, various catalysts have been developed for this transformation, including organocatalysts (e.g., Schiff bases [11] and ionic liquids [12-17]), metal complexes (e.g., salen complexes [18] and metalloporphyrins [19]). Among these catalysts, ionic liquids (ILs), such as ammonium [12,13], phosphonium [14], imidazolium [15,16], and pyridinium salts [17], have shown high catalytic activity for $\mathrm{CO}_{2}$-epoxide cycloaddition. Regrettably, these homogeneous catalysts are not easily separated from the organic constituents of the reaction mixture, limiting their large-scale applications. In order to overcome this issue, the development of IL-based heterogeneous catalysts is considered an effective alternative solution. Accordingly, ILs have been successfully grafted to various solid supports, including silica materials [20-22], polymers [23-25],

\footnotetext{
*Corresponding author. Tel: +86-28-65726196; E-mail: caihuaqiang@caep.cn

\# Corresponding author. Tel: +86-635-3481095; E-mail: jingxuechao@lxhg.com

DOI: S1872-2067(19)63487-X | http://www.sciencedirect.com/science/journal/18722067 | Chin. J. Catal., Vol. 41, No. 3, March 2020
} 
and metal-organic frameworks [26,27].

Covalent organic frameworks (COFs) are a class of crystalline porous organic polymers composed of light-weight elements and constructed via strong covalent bonds [28-30]. Due to their unique physical and chemical properties, COFs have been widely used for gas adsorption-separation, and in the photoelectric field, catalytic field, as well as other fields [31,32]. Especially in the catalysis field, the flexible regulation of pore parameters, including pore size, shape, pore volume, and size distribution, as well as the easy introduction of catalytically active sites to the framework of COFs render these materials promising platforms for the immobilization of catalysts in organic synthesis. In particular, one-dimensional (1D) open channels found in 2D-COFs would not only remarkably enhance the diffusion of substances, but can also be used to immobilize catalysts through the post-modification of the building blocks of COFs. As such, some reactions have been conducted using COFs as catalysts, such as the Michael addition reaction [33], Diels-Alder reaction [34], oxygen evolution reaction [35] and Heck-epoxidation tandem reaction [36]. Recently, the concept of incorporating ILs into COFs has been realized by our group and others [37-40]. COF materials can thus be used as an ideal catalyst or catalyst carrier in a heterogeneous reaction process.

To further explore the application of the COFs in heterogeneous catalysis, in this study, we have immobilized an IL, 1-alkyl-3-methylimidazolium bromide, on the microporous channel walls of $\mathrm{H}_{2} \mathrm{P}-\mathrm{DHPh} \mathrm{COF}$ through a two-step modification step (Scheme 1). The $\mathrm{H}_{2} \mathrm{P}-\mathrm{DHPh}$ COF material was first prepared and selected in terms of its special pore structures, high surface area, and abundant surface hydroxyl groups. The as-synthesized catalyst (AMIMBr@ $\left.\mathrm{H}_{2} \mathrm{P}-\mathrm{DHPh}\right)$ was character-
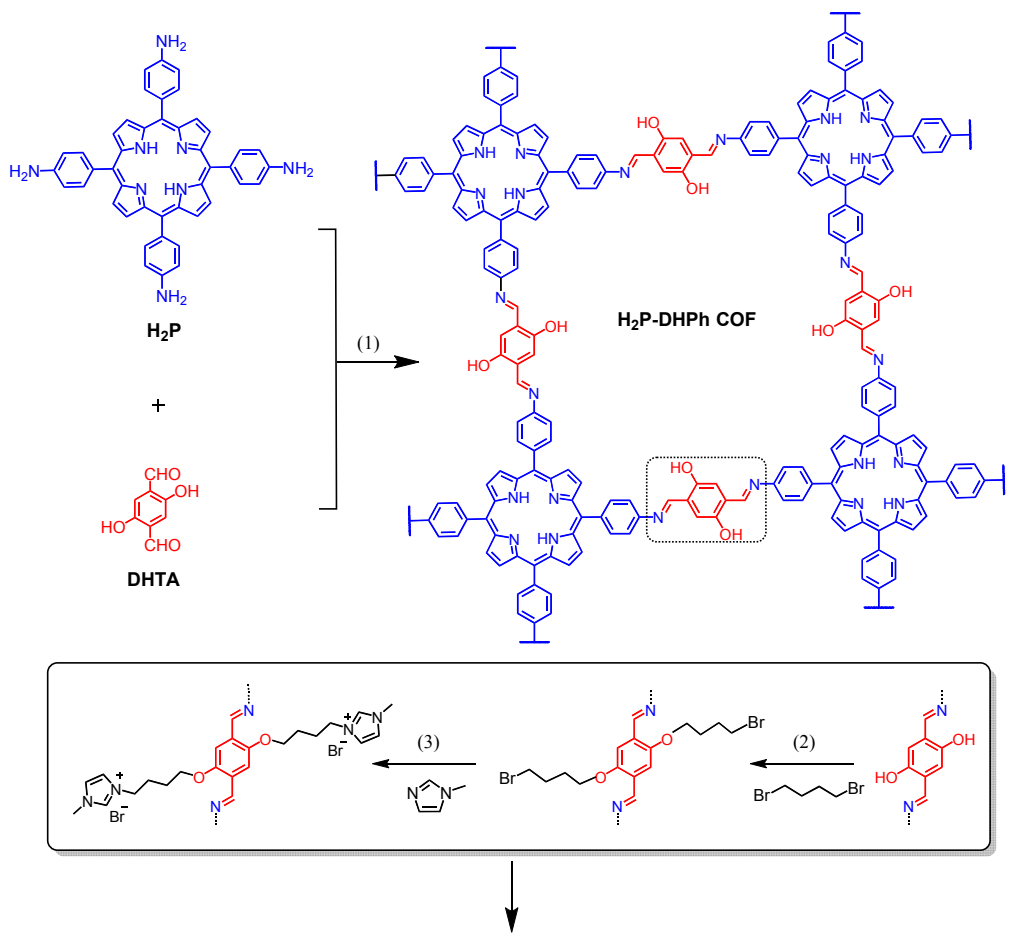

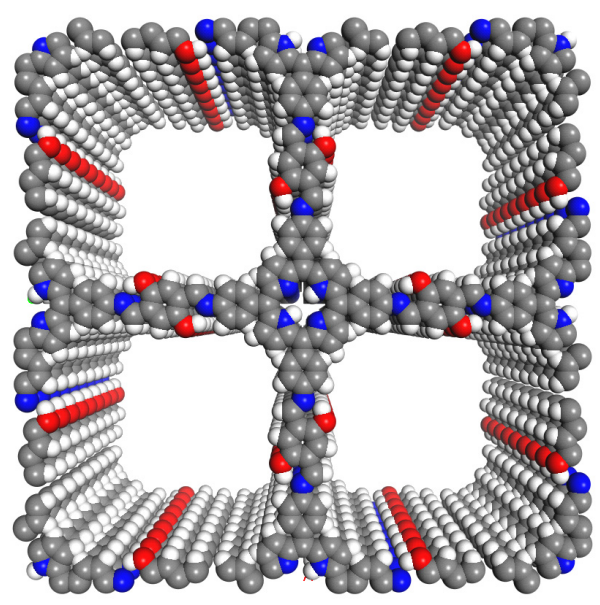

$\mathrm{H}_{2} \mathrm{P}-\mathrm{DHPh}$ COF Surface modification $\gamma$

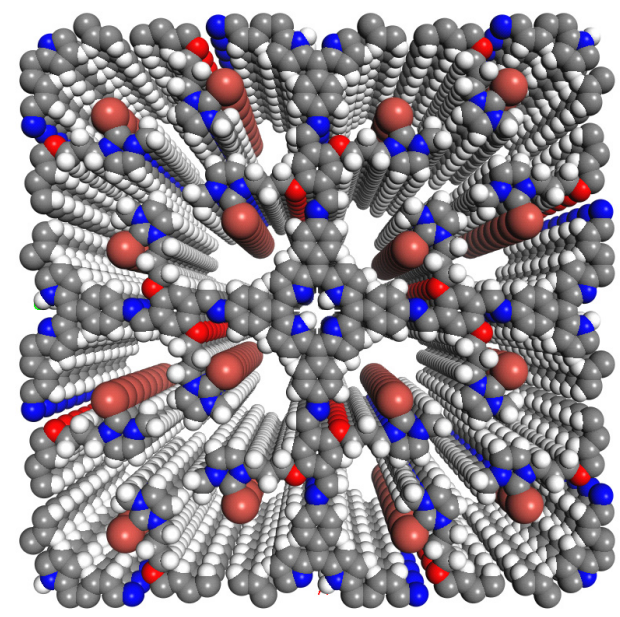

AMIMBr@ ${ }_{2}$ P-DHPh COF

Scheme 1. The synthesis procedure of AMIMBr@ $\mathrm{H}_{2} \mathrm{P}-\mathrm{DHPh}$ COF. 
ized and evaluated for the coupling of $\mathrm{CO}_{2}$ and epoxides. Moreover, the recyclability of our catalyst system was examined for a selected coupling reaction between $\mathrm{CO}_{2}$ and epichlorohydrin.

\section{Experimental}

\subsection{Materials}

All the reagents were used as received without further purification. Pyrrole, 4-nitrobenzaldehyde, 1,4-dimethoxybenzene, deuterium chloride, 1,2-dichlorobenzene (o-DCB), and 1-butanol $(n-\mathrm{BuOH})$ were purchased from TCI Chemicals. Hexamethylenetetramine, potassium carbonate, acetic acid, acetic anhydride, pyridine, 1,4-dioxane, formaldehyde, hydrochloric acid, sulfuric acid, chloroform, acetone, tetrahydrofuran (THF), dichloromethane, ethyl acetate, hydrobromic acid, magnesium sulfate, methanol, ammonia solution, 1,4-dibromobutane, propionic acid, Tin(II) chloride, and 1-methylimidazole were purchased from Sinopharm Chemical Reagent Co.

\subsection{Synthesis}

Synthesis of building blocks. 5,10,15,20-Tetrakis(p-tetraphenylamino)porphyrin $\left(\mathrm{H}_{2} \mathrm{P}\right)$ and 2,5-dihydroxyterephthalaldehyde (DHTA) were prepared according to reported procedures $[41,42]$.

Synthesis of $\mathrm{H}_{2} \mathrm{P}-\mathrm{DHPh}$ COF. $\mathrm{H}_{2} \mathrm{P}(27.0 \mathrm{mg}, 0.04 \mathrm{mmol})$, and DHTA (13.5 mg, $0.08 \mathrm{mmol}$ ) were placed in a glass ampule vessel $(10 \mathrm{~mL})$, followed by the addition of a solution of $o$-DCB $/ n-\mathrm{BuOH} / 3 \mathrm{M}$ acetic acid (5/5/1 by volume; $2.2 \mathrm{~mL}$ ) [42]. The mixture was sonicated for $10 \mathrm{~min}$, then flash-frozen in liquid nitrogen, and degassed by three freeze-pump-thaw cycles. The tube was flame-sealed, then heated at $120{ }^{\circ} \mathrm{C}$ for $3 \mathrm{~d}$. The resulting precipitate was filtered out, washed sequentially with THF (five times) and acetone (three times) to give a purple colored powder, which was dried at $120{ }^{\circ} \mathrm{C}$ under vacuum overnight to give the desired product in $70 \%$ yield.

Synthesis of AMIMBr@H $\mathrm{H}_{2} \mathrm{P}$-DHPh COF. $\mathrm{H}_{2} \mathrm{P}$-DHPh COF (40 $\mathrm{mg}$ ) and potassium carbonate (118.4 $\mathrm{mg}$ ) were weighed into a 50-mL glass vial, to which dehydrated THF $(10 \mathrm{~mL})$ was added. The mixture was heated at reflux. To the hot mixture, 1,4-dibromobutane $(1 \mathrm{~mL})$ was added, and the mixture was maintained at reflux, and stirred overnight in nitrogen atmosphere. After cooling the mixture to room temperature, the precipitate of the product was collected by filtration, washed with water and acetone. The powder was dried overnight under vacuum at $80{ }^{\circ} \mathrm{C}$ to give the corresponding product of BuBr@ $\mathrm{H}_{2} \mathrm{P}-\mathrm{DHPh}$ COF, quantitatively.

The obtained BuBr@ $\mathrm{H}_{2} \mathrm{P}-\mathrm{DHPh} \quad \mathrm{COF}$ was stirred in 1-methylimidazole $(5 \mathrm{~mL})$ at $80{ }^{\circ} \mathrm{C}$ under nitrogen protection for $4 \mathrm{~h}$. After cooling down to room temperature, the solvent was removed. The residue was washed thoroughly with water and acetone to get the targeted product AMIMBr@ $\mathrm{H}_{2} \mathrm{P}-\mathrm{DHPh}$ COF.

Hydrolysis of AMIMBr@H $\mathrm{H}_{2} \mathrm{P}$-DHPh COF. The AMIMBr@ $\mathrm{H}_{2} \mathrm{P}-$ DHPh COF (2 mg) sample was hydrolyzed by a DMSO-d6/DCl
(4/1 by vol., $1 \mathrm{~mL}$ ) solution [43]. The mixture was sonicated for over 15 min to obtain a homogenous solution. The content of 1-alkyl-3-methylimidazole was calculated from the proton integrates of its ${ }^{1} \mathrm{H}$ NMR spectrum.

\subsection{General procedures for carboxylation of epoxides with $\mathrm{CO}_{2}$}

All the reactions were carried out in a $60-\mathrm{mL}$ stainless steel reactor with a glass-lined tank. The mixture of epoxides (7.5 mmol) and AIMIBr@ $\mathrm{H}_{2} \mathrm{P}-\mathrm{DHPh}$ COF (10 mg) was added to the reactor without solvent. The reactor was pressurized with $\mathrm{CO}_{2}$ $(1.0 \mathrm{MPa})$, and the temperature was raised to $120^{\circ} \mathrm{C}$. The reaction was conducted for $24 \mathrm{~h}$. After the reaction, the reactor was cooled down in ice-cold water. Unreacted $\mathrm{CO}_{2}$ was vented out, and the catalyst was separated by centrifugation. The products were analyzed by gas chromatography (Agilent HP 6890 A) using a capillary column (HP-5, $30 \mathrm{~m} \times 0.25 \mathrm{~mm}$ ) and a flame ionization detector. The product yield was determined by using toluene as an internal standard.

\subsection{Characterization}

Fourier-transform infrared (FTIR) spectroscopy was carried out on a Bruker spectrophotometer (Model TENSOR27) with powder-pressed $\mathrm{KBr}$ pellets. Powder X-ray diffraction (PXRD) analysis was carried out on a Rigaku RINT D/Max 2500 powder diffraction system, using a $\mathrm{Cu} K \alpha$ radiation $(\lambda=1.5432 \AA)$. Thermogravimetric analysis (TGA, STA449F3, NETZSCH, Germany) was performed by heating from room temperature to above $800{ }^{\circ} \mathrm{C}$ at a rate of $10^{\circ} \mathrm{C} \mathrm{min}^{-1}$ and a $\mathrm{N}_{2}$ flow rate of 20 $\mathrm{mL} \min ^{-1}$. The nitrogen physisorption experiment was conducted at $77 \mathrm{~K}$ on a QUADRASORB SI gas sorption system (Quantachrome Instruments), which was degassed at $120^{\circ} \mathrm{C}$ in vacuum before testing. The specific surface areas were calculated by the Brunauer-Emmett-Teller (BET) method. The pore size distribution was evaluated by the nonlocal density functional theory (NLDFT) method. Gas chromatography (GC, Agilent 7890A) equipped with a capillary column (HP-5, $30 \mathrm{~m} \times$ $0.25 \mathrm{~mm}$ ) using a flame ionization detector. ${ }^{1} \mathrm{H}$ and ${ }^{13} \mathrm{C}$ nuclear magnetic resonance (NMR) spectra were recorded on a Bruker Advance III 400-MHz NMR spectrometer (Bruker BioSpin Corporation, Fällanden, Switzerland).

\section{Results and discussion}

\subsection{Characterization of COFs}

Herein we designed and prepared a two-dimensional cationic covalent organic framework by a post-synthesis strategy. A porous imine-linked porphyrin $\mathrm{COF}, \mathrm{H}_{2} \mathrm{P}-\mathrm{DHPh} \mathrm{COF}$, was utilized as the precursor, which was initially synthesized by a two-component condensation system. AMIMBr@ $\mathrm{H}_{2} \mathrm{P}-\mathrm{DHPh}$ COF was synthesized through three main steps: (1) preparation of the $\mathrm{H}_{2} \mathrm{P}-\mathrm{DHPh}$ COF according to a known procedure described by Jiang et al. [42]; (2) post-modification of $\mathrm{H}_{2} \mathrm{P}-\mathrm{DHPh}$ COF with excess 1,4-dibromobutane to obtain an alkyl halide-grafted BuBr@ $\mathrm{H}_{2} \mathrm{P}-\mathrm{DHPh}$ COF through an etherification 

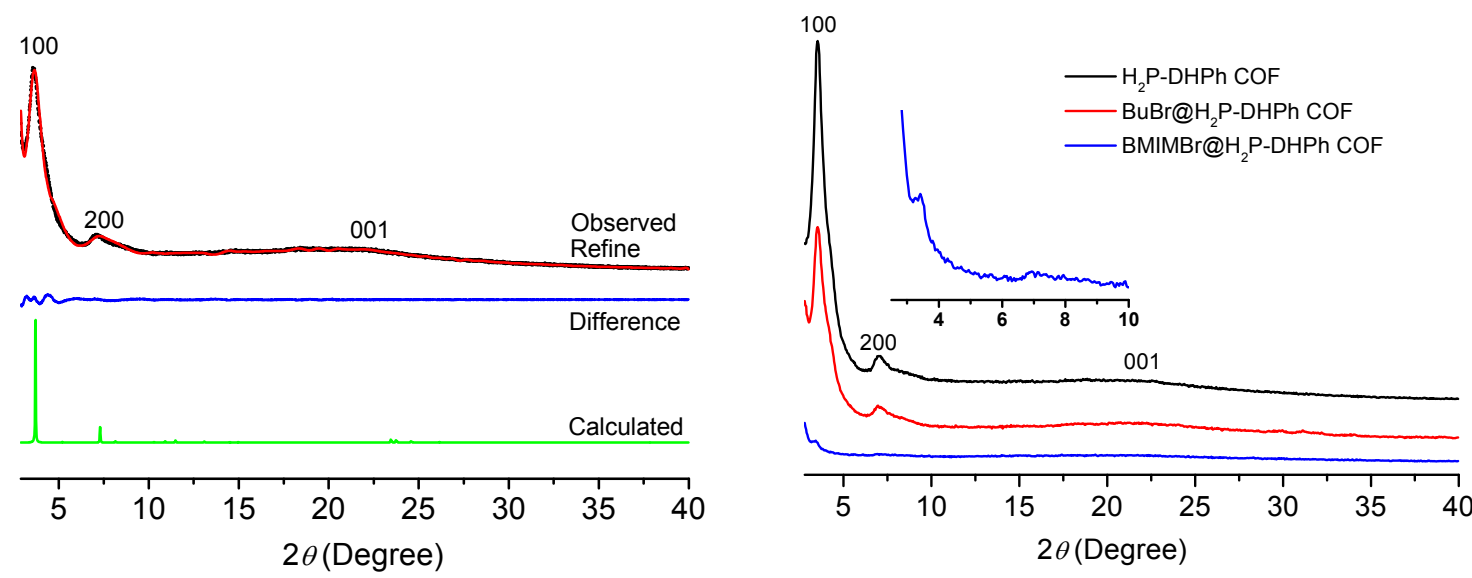

Fig. 1. (a) PXRD patterns of $\mathrm{H}_{2} \mathrm{P}-\mathrm{DHPh}$ COF. Observed XRD pattern (black) and profiles simulated using the Pawley refinement (red), their difference (blue), and AA-stacking modes (green) of the $\mathrm{H}_{2} \mathrm{P}-\mathrm{DHPh}$ COF; (b) Comparison of PXRD patterns of $\mathrm{H}_{2} \mathrm{P}-\mathrm{DHPh} \mathrm{COF}, \mathrm{BuBr} @ \mathrm{H}_{2} \mathrm{P}-\mathrm{DHPh} \mathrm{COF}$, and AMIMBr@ $\mathrm{H}_{2} \mathrm{P}-\mathrm{DHPh}$ COF.

reaction that used potassium carbonate as a neutralizing reagent; (3) ionization of the $\mathrm{BuBr} @ \mathrm{H}_{2} \mathrm{P}-\mathrm{DHPh}$ COF to AMIMBr@ $\mathrm{H}_{2} \mathrm{P}-\mathrm{DHPh}$ COF using 1-methylimidazole through a quaternization reaction. The general pathway is represented in Scheme 1.

The crystalline structures and unit cell parameters of $\mathrm{H}_{2} \mathrm{P}$-DHPh COF were first determined by PXRD analysis in combination with structural simulations. Diffraction peaks of $\mathrm{H}_{2} \mathrm{P}-\mathrm{DHPh}$ COF were observed at $2 \theta=3.5^{\circ}, 7.1^{\circ}$, and $22.9^{\circ}$, which were attributed to the (100), (200), and (001) facets, respectively (Fig. 1(a), black curve). The use of lattice modeling and Pawley refinement processes led to an eclipsed AA stacking model that could reproduce the PXRD results with regards to the peak position and intensity (Fig. 1(a), green curve). The Pawley refinement (Fig. 1(a), red curve) using a unit cell of $\alpha=$ $\gamma=90^{\circ}, \beta=89.98^{\circ}, a=24.53 \AA, b=3.80 \AA$, and $c=24.52 \AA$ confirmed the peak assignment, as evidenced by their negligible difference (Fig. 1(a), blue curve). The pseudo-Voigt function was used for whole profile fitting, and the Berar-Baldinozzi method was used for asymmetry correction during the refinement processes. The final Rwp and Rp values were $4.63 \%$ and $3.62 \%$, respectively, for the $\mathrm{H}_{2} \mathrm{P}-\mathrm{DHPh}$ COF. Clearly, the crystalline structure of $\mathrm{H}_{2} \mathrm{P}-\mathrm{DHPh}$ COF was the same as was reported by Jiang et al. [42].

After grafting 1,4-dibromobutane and 1-methylimidazole successively onto the channel walls of $\mathrm{H}_{2} \mathrm{P}-\mathrm{DHPh} \mathrm{COF}$, all the reflection peak positions for the modified samples BuBr@ $\mathrm{H}_{2} \mathrm{P}-\mathrm{DHPh}$ COF and AMIMBr@ $\mathrm{H}_{2} \mathrm{P}-\mathrm{DHPh}$ COF were similar to those for the as-synthesized $\mathrm{H}_{2} \mathrm{P}$-DHPh COF, indicating that they possessed similar crystal structures (Fig. 1(b)). A similar situation was also observed in our previous study [39]. When BuBr@ $\mathrm{H}_{2} \mathrm{P}-\mathrm{DHPh}$ COF was further ionized through the quaternization of 1-methylimidazole, the reflection peaks were significantly decreased, suggesting the occupation of the pores by the grafted IL. We do not exclude the possibility of undesirable damage to the crystal structure of $\mathrm{H}_{2} \mathrm{P}-\mathrm{DHPh} \mathrm{COF}$ during the post-modification and ionization processes [44].

The immobilization of 1,4-dibromobutane and further 1-methylimidazole on $\mathrm{H}_{2} \mathrm{P}$-DHPh COF has been characterized by FT-IR spectroscopy, $\mathrm{N}_{2}$ adsorption-desorption, and TGA techniques. Fig. 2 shows the FT-IR spectra of $\mathrm{H}_{2} \mathrm{P}-\mathrm{DHPh}$ COF,

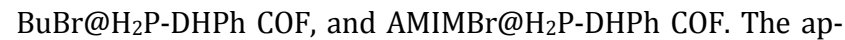
pearance of an intensive band around $1620 \mathrm{~cm}^{-1}$ in $\mathrm{H}_{2} \mathrm{P}-\mathrm{DHPh}$ COF confirmed the formation of imine bonds. After post-modification and ionization, the $\mathrm{C}=\mathrm{N}$ bands were retained, suggesting that the covalent connectivity of the frameworks was maintained. A weak peak also appeared at $660 \mathrm{~cm}^{-1}$ in the FT-IR spectrum of $\mathrm{BuBr} @ \mathrm{H}_{2} \mathrm{P}-\mathrm{DHPh} \mathrm{COF}$, corresponding to $\mathrm{C}$-Br stretching vibrations of 1,4-dibromobutane, indicating the success of the etherification reaction. Furthermore, a peak at $1556 \mathrm{~cm}^{-1}$ was also observed, which can be assigned to the $\mathrm{C}=\mathrm{C}$ band of the 1-methylimidazole group, revealing that the 1-methylimidazole groups were successfully grafted onto the channel walls of the BuBr@ $\mathrm{H}_{2} \mathrm{P}-\mathrm{DHPh}$ COF.

The porous properties of these COFs were determined from the nitrogen adsorption-desorption isotherms recorded at 77 K. As shown in Fig. 3(a), these COF materials exhibited the typical type-IV isotherms with an H4 hysteresis loop. The BET

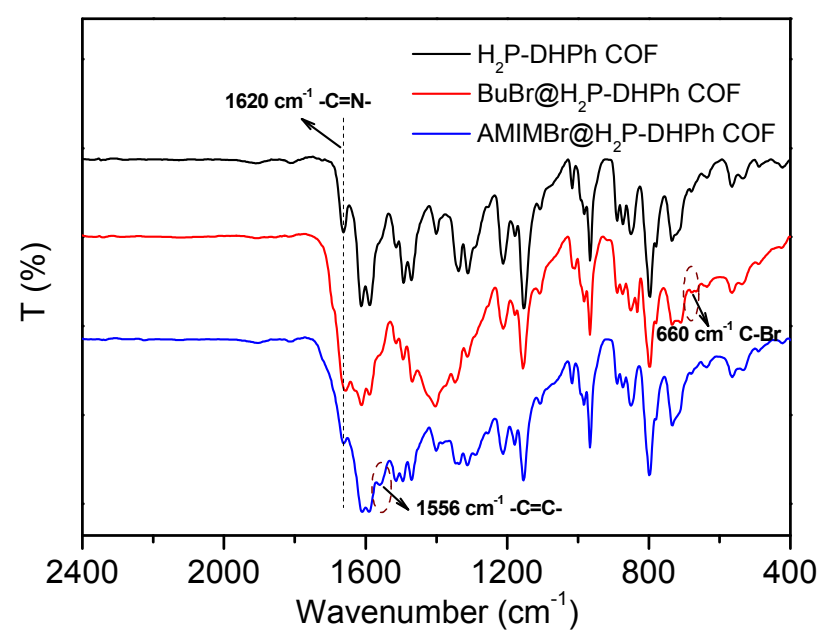

Fig. 2. FT-IR spectra of $\mathrm{H}_{2} \mathrm{P}-\mathrm{DHPh} \mathrm{COF}, \mathrm{BuBr} @ \mathrm{H}_{2} \mathrm{P}-\mathrm{DHPh} \mathrm{COF}$, and AMIMBr@ $\mathrm{H}_{2} \mathrm{P}-\mathrm{DHPh}$ COF. 
a)

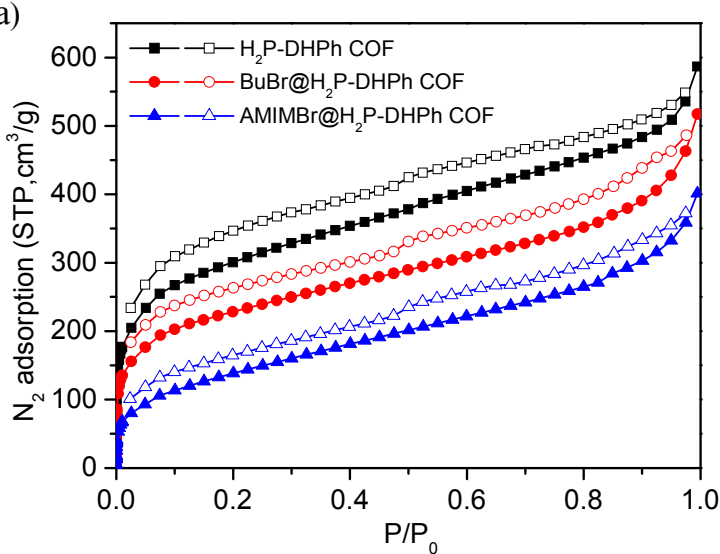

b)

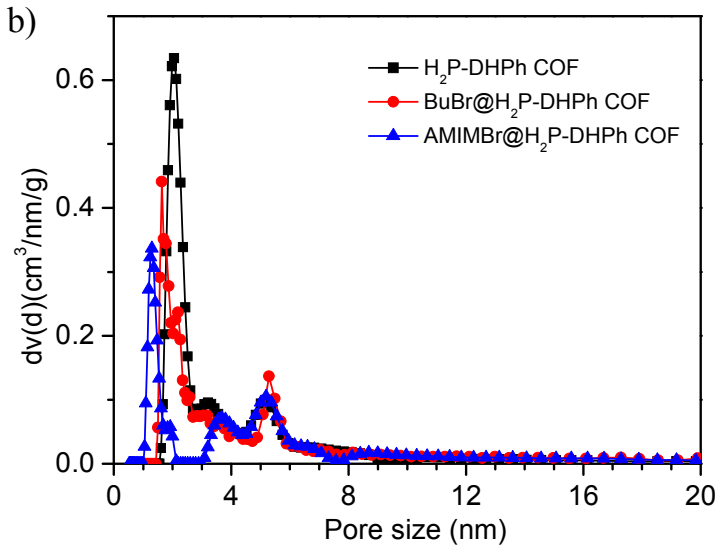

Fig. 3. $\mathrm{N}_{2}$ adsorption-desorption isotherms recorded at $77 \mathrm{~K}$ (a) and the corresponding DFT pore-size distributions (b) of the COFs.

surface areas were measured to be 1123,856 , and $513 \mathrm{~m}^{2} \mathrm{~g}^{-1}$ for $\mathrm{H}_{2} \mathrm{P}-\mathrm{DHPh} \quad \mathrm{COF}, \mathrm{BuBr} @ \mathrm{H}_{2} \mathrm{P}-\mathrm{DHPh} \quad \mathrm{COF}$, and AMIMBr@ $\mathrm{H}_{2} \mathrm{P}-\mathrm{DHPh}$ COF, while their corresponding total pore volumes were $0.91,0.80$, and $0.62 \mathrm{~cm}^{3} \mathrm{~g}^{-1}$. The pore size distributions of the different samples were evaluated by DFT. The pore diameter gradually decreased from 2.0 to $1.3 \mathrm{~nm}$ when $\mathrm{H}_{2} \mathrm{P}$-DHPh COF was modified through 1,4-dibromobutane and 1-methylimidazole, successively; this result is consistent with that of the PXRD patterns. Despite the occupation of the pores by the grafted IL, AMIMBr@ $\mathrm{H}_{2} \mathrm{P}-\mathrm{DHPh}$ COF maintained a porosity of up to $513 \mathrm{~m}^{2} \mathrm{~g}^{-1}$. The porosity data of the COFs are summarized in Table 1. It needs to be clarified that the intensity of the diffraction peaks of AMIMBr@ $\mathrm{H}_{2} \mathrm{P}-\mathrm{DHPh}$ COF was remarkably decreased when 1-methylimidazole was introduced into the channels of $\mathrm{BuBr} @ \mathrm{H}_{2} \mathrm{P}-\mathrm{DHPh}$ COF. The reason is that the COFs are comprised of light elements, like C, H, O, and N. All these light elements have weak scattering powers, leading to a low-resolution XRD pattern. Therefore, we consider that the ordered framework structure remained intact to a certain extent, even though the $\mathrm{H}_{2} \mathrm{P}-\mathrm{DHPh}$ COF was successively modified twice. The thermal behavior of these COFs was studied by thermogravimetric analysis (TGA). TGA showed good thermal stability for these as-prepared materials, which survived up to $300{ }^{\circ} \mathrm{C}$ without decomposing. The high porosity and good thermal stability of the COFs mean that these COFs can be used as catalysts or catalyst carriers.

The content of the 1-methylimidazole groups grafted onto the channel walls of BuBr@ $\mathrm{H}_{2} \mathrm{P}-\mathrm{DHPh}$ COF was analyzed by ${ }^{1} \mathrm{H}$ NMR spectroscopy. The AMIMBr@ $\mathrm{H}_{2} \mathrm{P}-\mathrm{DHPh}$ COF sample was digested with DCl (6 M) in DMSO-d6. We found that about 16 mol\% 1-methylimidazole was grafted onto the channel walls of the COF, i.e. the content of 1-methylimidazole on the AMIMBr@ $\mathrm{H}_{2} \mathrm{P}-\mathrm{DHPh}$ COF was calculated to be 4.9 wt $\%$. It is

Table 1

Porosity parameters of the COFs obtained from the $\mathrm{N}_{2}$ adsorption-desorption isotherms recorded at $77 \mathrm{~K}$.

\begin{tabular}{|c|c|c|c|}
\hline Materials & $S_{\text {BET }}\left(\mathrm{m}^{2} \mathrm{~g}^{-1}\right)$ & Pore size $(\mathrm{nm})$ & $V_{\text {total }}\left(\mathrm{m}^{3} \mathrm{~g}^{-1}\right)$ \\
\hline $\mathrm{H}_{2} \mathrm{P}-\mathrm{DHPh} \mathrm{COF}$ & 1123 & 2.0 & 0.91 \\
\hline $\mathrm{BuBr} @ \mathrm{H}_{2} \mathrm{P}-\mathrm{DHPh} \mathrm{COF}$ & 856 & 1.6 & 0.80 \\
\hline AMIMBr@ $\mathrm{H}_{2} \mathrm{P}-\mathrm{DHPh}$ COF & 513 & 1.3 & 0.62 \\
\hline
\end{tabular}

worth noting that an excessive ionization of the pores will lead to the exfoliation of the nanosheets of 2D-COFs [45]; therefore, the reaction time was limited to $4 \mathrm{~h}$.

\section{2. $\mathrm{CO}_{2}$ adsorption of COFs.}

The $\mathrm{CO}_{2}$ adsorption capability of the COFs was first investigated in this work. The $\mathrm{CO}_{2}$ adsorption isotherms of $\mathrm{H}_{2} \mathrm{P}-\mathrm{DHPh}$ COF and AMIMBr@ $\mathrm{H}_{2} \mathrm{P}-\mathrm{DHPh}$ COF were measured at pressures of up to 1 bar at 0 and $25^{\circ} \mathrm{C}$, respectively. AMIMBr@ $\mathrm{H}_{2} \mathrm{P}-\mathrm{DHPh}$ COF exhibited a relatively higher adsorption capacity than that of $\mathrm{H}_{2} \mathrm{P}$-DHPh COF at $0{ }^{\circ} \mathrm{C}$, although the specific surface area of AMIMBr@ $\mathrm{H}_{2} \mathrm{P}-\mathrm{DHPh}$ COF was remarkably reduced after modification because the decreased pore size would enhance the interaction between $\mathrm{CO}_{2}$ guest molecules and the pore surface of the COF [46]. The introduction of highly charged groups on the surface of porous materials can afford high affinities for $\mathrm{CO}_{2}$ due to the high quadrupole moment of $\mathrm{CO}_{2}$ [46]. $\mathrm{H}_{2} \mathrm{P}-\mathrm{DHPh} \mathrm{COF}$ and AMIMBr@ $\mathrm{H}_{2} \mathrm{P}-\mathrm{DHPh}$ COF exhibited $\mathrm{CO}_{2}$ uptake capacities of 31.9 , and $31.4 \mathrm{~cm}^{3} \mathrm{~g}^{-1}$ (approximately 6.3 and $6.2 \mathrm{wt} \%$ ) at 0 ${ }^{\circ} \mathrm{C}$ and $1 \mathrm{bar}$, which decreased to 23.9 and $22.0 \mathrm{~cm}^{3} \mathrm{~g}^{-1}$ (approximately 4.3 and $4.0 \mathrm{wt} \%$ ), respectively, when the temperature was increased to $25^{\circ} \mathrm{C}, 1$ bar (Fig. 5(a)). The $\mathrm{CO}_{2}$ adsorption isotherms of the COFs were calculated to be $35.8 \mathrm{~kJ} \mathrm{~mol}^{-1}$

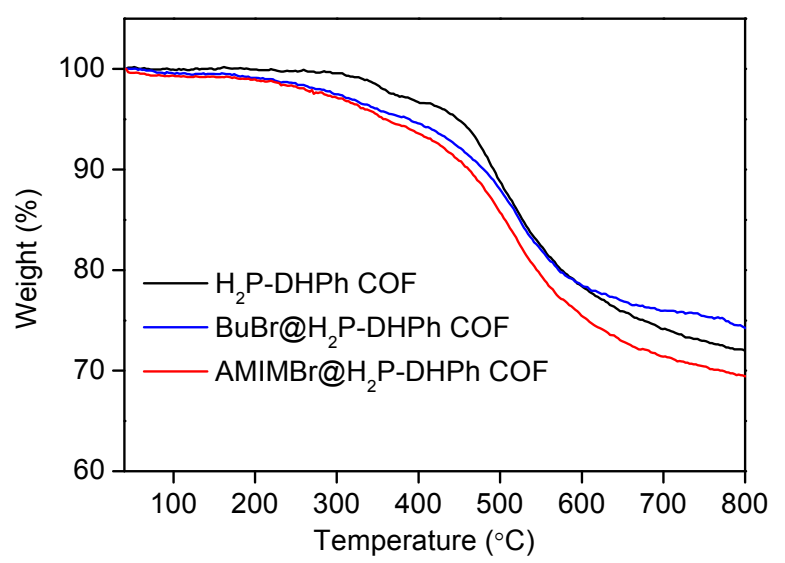

Fig. 4. TGA curves of $\mathrm{H}_{2} \mathrm{P}-\mathrm{DHPh} \mathrm{COF}, \mathrm{BuBr} @ \mathrm{H}_{2} \mathrm{P}-\mathrm{DHPh} \mathrm{COF}$, and AMIMBr@ $\mathrm{H}_{2} \mathrm{P}-\mathrm{DHPh}$ COF. 

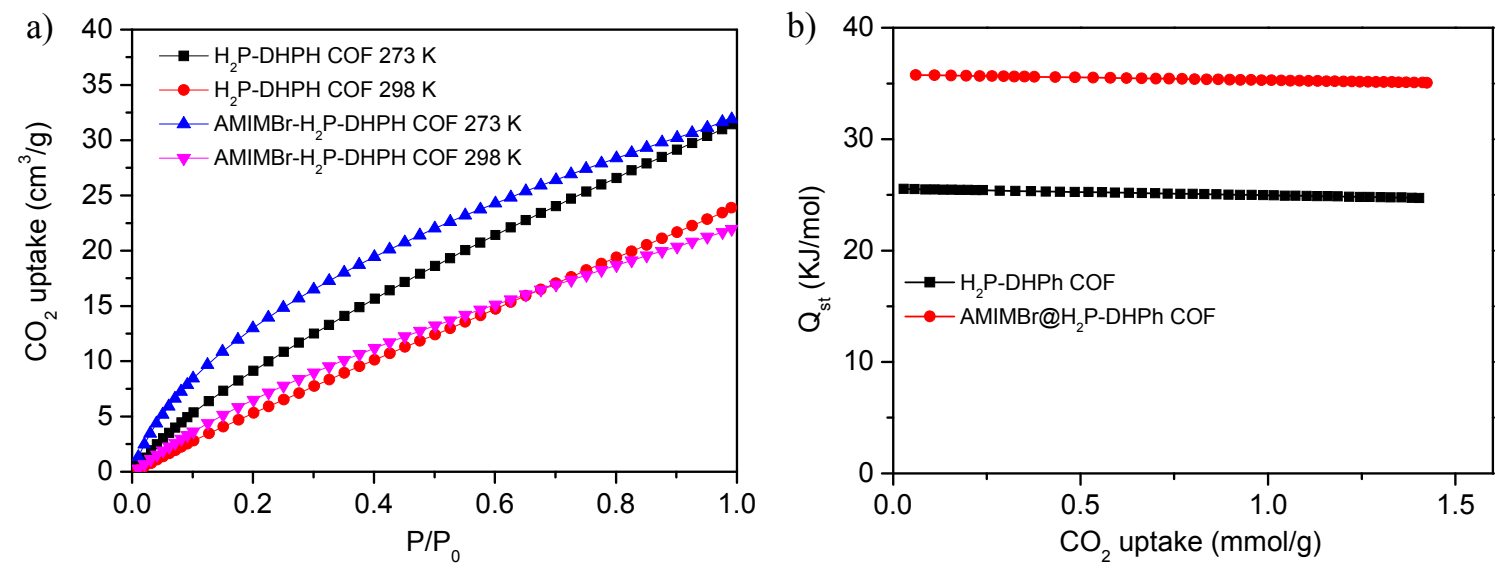

Fig. 5. (a) $\mathrm{CO}_{2}$ adsorption isotherms of COFs recorded at $0{ }^{\circ} \mathrm{C}$ (solid symbol) and $25^{\circ} \mathrm{C}$ (open symbol); (b) the respective isosteric heats of adsorption for $\mathrm{CO}_{2}$ of $\mathrm{H}_{2} \mathrm{P}-\mathrm{DHPh} \mathrm{COF}$ and AMIMBr@ $\mathrm{H}_{2} \mathrm{P}-\mathrm{DHPh} \mathrm{COF}$.

for AMIMBr@ $\mathrm{H}_{2} \mathrm{P}-\mathrm{DHPh}$ COF and $25.5 \mathrm{~kJ} \mathrm{~mol}-1$ for $\mathrm{H}_{2} \mathrm{P}-\mathrm{DHPh}$ COF (Fig. 5(b)), confirming that there are stronger interactions between $\mathrm{CO}_{2}$ and the pore surface of AMIMBr@ $\mathrm{H}_{2} \mathrm{P}-\mathrm{DHPh}$ COF than the pore surface of $\mathrm{H}_{2} \mathrm{P}-\mathrm{DHPh} \mathrm{COF}$. The high $\mathrm{CO}_{2}$ adsorption capability of the COF makes it possible for AMIMBr@ $\mathrm{H}_{2} \mathrm{P}-\mathrm{DHPh}$ COF to exhibit excellent catalytic performance for the cycloaddition of $\mathrm{CO}_{2}$ to epoxides.

\subsection{Catalytic performance of COFs}

To test the catalytic performance of the obtained COF catalyst, the cycloaddition of $\mathrm{CO}_{2}$ to epoxides was chosen as the probe reaction in this study. The reaction conditions were carried out at $120^{\circ} \mathrm{C}, 1.0 \mathrm{MPa} \mathrm{CO}_{2}$, and a reaction time of $24 \mathrm{~h}$. The experimental results are shown in Table 2 . In the absence of the catalyst, a conversion of $38 \%$ of the epichlorohydrin to the cyclic carbonate can be obtained under the above reaction conditions (Table 2, entry 1). A similar result (a conversion of 40\%) was obtained when the same experiment was repeated with $\mathrm{H}_{2} \mathrm{P}-\mathrm{DHPh}$ COF as a heterogeneous catalyst (Table 2, entry 2). However, a conversion of $91 \%$ was observed when functionalized AMIMBr@H $\mathrm{H}_{2} \mathrm{P}-\mathrm{DHPh}$ COF was used as the catalyst (Table 2 , entry 3), indicating the outstanding catalytic performance of AMIMBr@H $\mathrm{H}_{2} \mathrm{P}-\mathrm{DHPh}$ COF.

The catalytic activity of AMIMBr@ $\mathrm{H}_{2} \mathrm{P}-\mathrm{DHPh}$ COF in the cycloaddition of $\mathrm{CO}_{2}$ to different epoxides under identical conditions has been examined. The epoxides used for this purpose include propylene oxide, 1,2-epoxyhexane, 1,2-epoxyoctane, butyl glycidyl ether, and styrene oxide (Table 2, entries 4-8). The catalytic ability of AMIMBr@ $\mathrm{H}_{2} \mathrm{P}-\mathrm{DHPh}$ COF was more effective for the smaller epoxides (such as epichlorohydrin and propylene oxide with $91 \%$ and $95 \%$ conversions, respectively) than the epoxides with longer alkyl chains, such as 1,2-epoxyoctane (16\% conversion) and butyl glycidyl ether (21\% conversion). These results could be ascribed to the limited space in the channels of AMIMBr@H $2 \mathrm{P}-\mathrm{DHPh}$ COF, which gave an obvious size-selectivity towards epoxides.

The reusability of the as-synthesized AMIMBr@ $\mathrm{H}_{2} \mathrm{P}-\mathrm{DHPh}$ COF and the reproducibility of its catalytic performance has been investigated based on the experimental results of con- stant cyclic tests. In each cycle, AMIMBr@ $\mathrm{H}_{2} \mathrm{P}-\mathrm{DHPh}$ COF was removed by centrifugation and then rinsed with epichlorohydrin. After drying, the catalyst was reused for the next run. The yields of cyclic carbonate in the first five consecutive runs (Fig. 6) indicated that the catalytic activity of AMIMBr@ $\mathrm{H}_{2} \mathrm{P}-\mathrm{DHPh}$ COF could be retained for up to five cycloaddition series. After five runs, the BET surface area of AMIMBr@ $\mathrm{H}_{2} \mathrm{P}-\mathrm{DHPh}$ COF was measured to be $386 \mathrm{~m}^{2} \mathrm{~g}^{-1}$, suggesting that the high porosity nature of the COF catalyst remained. This result reveals that the 1-alkyl-3-methylimidazolium IL-modified COF can thus be considered a renewable and stable catalyst. The heterogeneous

\section{Table 2}

Coupling reactions of $\mathrm{CO}_{2}$ with various epoxides using AMIMBr@ $\mathrm{H}_{2} \mathrm{P}-\mathrm{DHPh}$ COF catalysts.

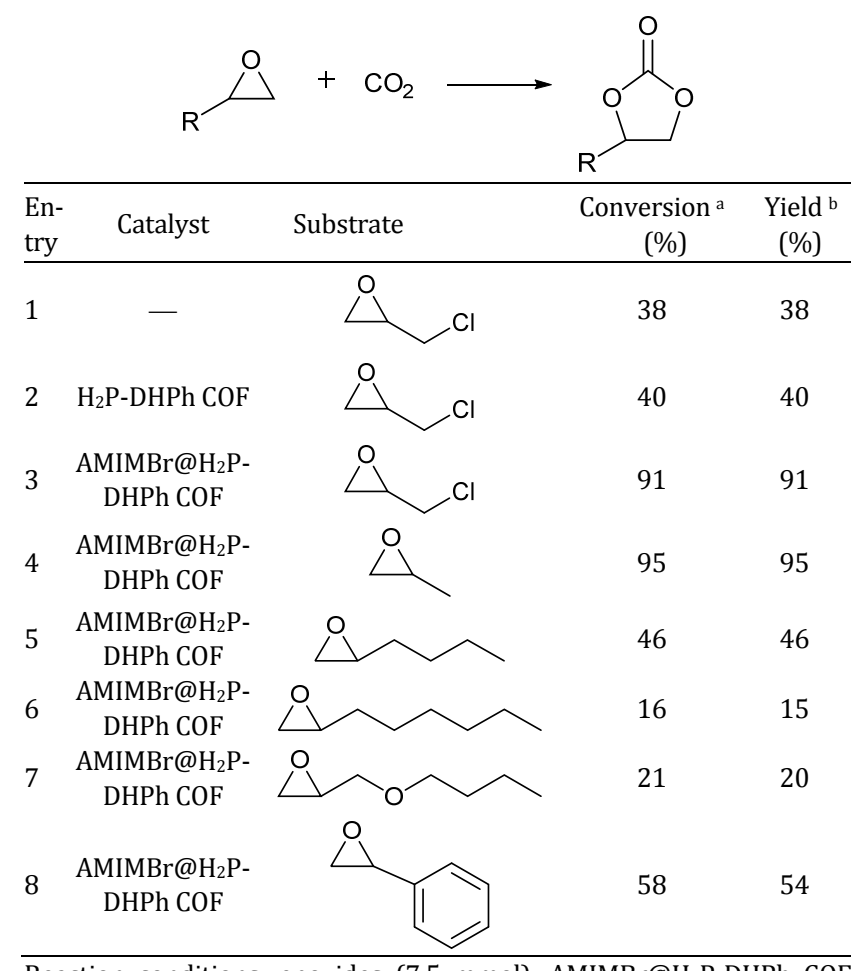

Reaction conditions: epoxides (7.5 mmol), AMIMBr@ $\mathrm{H}_{2} \mathrm{P}-\mathrm{DHPh}$ COF

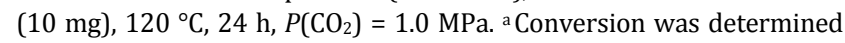
by Gas Chromatography (GC). ${ }^{\mathrm{b}}$ Isolated yield. 


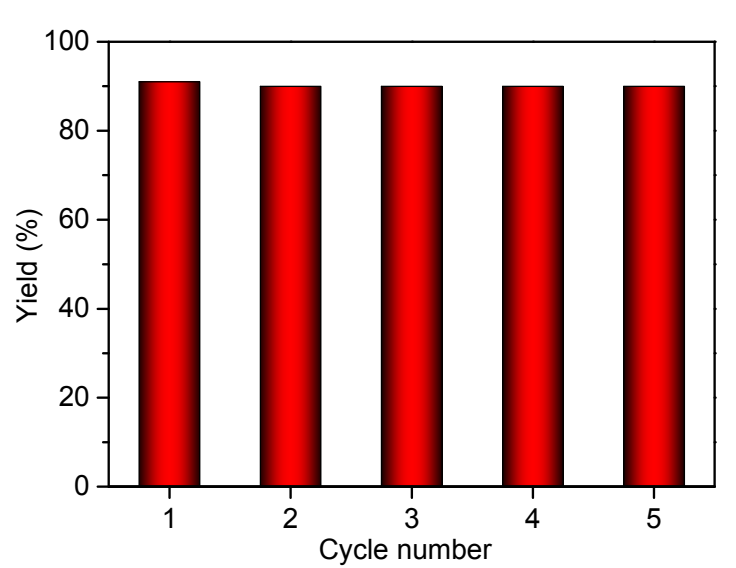

Fig. 6. The catalytic activity of recycled AMIMBr@ $\mathrm{H}_{2} \mathrm{P}-\mathrm{DHPh}$ COF.

nature of the COF catalyst was verified via a leaching test. In a typical experiment, the supernatant after one cycle of the catalytic reaction was isolated and mixed with fresh reactants for another cycle of the cycloaddition reaction without the heterogeneous catalyst. Expectedly, no target product was obtained under such conditions.

The data obtained from this study were compared to the activities of several other reported catalysts for the same reaction (Table 3). According to the data listed in Table 3, we can regard AMIMBr@ $\mathrm{H}_{2} \mathrm{P}-\mathrm{DHPh}$ COF as a prominent heterogeneous catalyst for the cycloaddition reaction because this synthesis can be carried out under relatively mild conditions compared to other catalysts, without a co-catalyst like a quaternary ammonium salt.

\section{Conclusions}

In summary, the ionic AMIMBr@ $\mathrm{H}_{2} \mathrm{P}-\mathrm{DHPh}$ COF was successfully synthesized by grafting IL onto the channel walls of $\mathrm{H}_{2} \mathrm{P}-\mathrm{DHPh} \mathrm{COF}$ and used as a catalyst for the synthesis of cyclic carbonates from epoxides and $\mathrm{CO}_{2}$ under mild reaction condi-

\section{Table 3}

Comparison with various catalysts in the performance of the coupling of propylene oxide and $\mathrm{CO}_{2}$.

\begin{tabular}{|c|c|c|c|c|}
\hline Catalyst & $\begin{array}{l}\text { Temp. } \\
\left({ }^{\circ} \mathrm{C}\right)\end{array}$ & $\begin{array}{c}\text { Pressure } \\
(\mathrm{MPa})\end{array}$ & $\begin{array}{l}\text { Yield } \\
(\%)\end{array}$ & Ref. \\
\hline AMIMBr@ $\mathrm{H}_{2} \mathrm{P}-\mathrm{DHPh} \mathrm{COF}$ & 120 & 1.0 & 95 & This work \\
\hline n-ZIF-90 & 120 & 1.0 & 49 & [27] \\
\hline Co(TPP)Cl/DMAP & 120 & 2.1 & 99 & [47] \\
\hline CTF-P-HSA & 130 & 0.69 & 65 & [8] \\
\hline $\mathrm{Zn}(0.15)-\mathrm{SBA}-15 / \mathrm{KI}$ & 120 & 1.0 & 98 & [5] \\
\hline Ti-SBA-15-pr-Ade (40) & 120 & 0.69 & 95.3 & [48] \\
\hline Al-SBA-15-HEPIMBr & 120 & 2.5 & 97.7 & [49] \\
\hline $\mathrm{MOF}-5 / \mathrm{n}-\mathrm{Bu}_{4} \mathrm{NBr}$ & 50 & 6.0 & 97.6 & {$[50]$} \\
\hline$[\mathrm{C} 4-\mathrm{mim}] \mathrm{BF}_{4}$ & 110 & 2.5 & 100 & [13] \\
\hline Quaternized chitosan & 120 & 1.2 & $88-89$ & [6] \\
\hline $\mathrm{Ni}$ (dioxime) $)_{2} / \mathrm{BMImPF}_{6}$ & 100 & 1.5 & 65 & [6] \\
\hline $\mathrm{HDBU} \cdot \mathrm{Cl}$ & 140 & 1.0 & 97 & [6] \\
\hline $\begin{array}{l}\text { Quaternized glycine, } \\
\left(\mathrm{HO}_{2} \mathrm{CCH}_{2} \mathrm{NMeH}\right) \mathrm{I}\end{array}$ & 120 & 1.2 & 84 & [6] \\
\hline (TBD·HBr) & 80 & 8.0 & 81 & [6] \\
\hline$[\mathrm{TEBA}]_{2} \mathrm{CaCl}_{4}$ & 170 & 4.0 & 97 & [6] \\
\hline
\end{tabular}

tions. The results show that this ionized porous COF material showed good catalytic activity even in a solvent-free and co-catalyst-free environment. The $\mathrm{H}_{2} \mathrm{P}-\mathrm{DHPh}$ COF with the immobilized IL significantly improved the catalytic activity as compared to the pure $\mathrm{H}_{2} \mathrm{P}-\mathrm{DHPh}$ COF. In addition, AMIMBr@H $\mathrm{H}_{2} \mathrm{P}-\mathrm{DHPh}$ COF showed apparent size-selectivity towards epoxides due to the limited space of the channels after a two-step modification. Furthermore, the AMIMBr@ $\mathrm{H}_{2} \mathrm{P}-\mathrm{DHPh}$ COF has been successfully recycled five times after easy separation, without deteriorating its activity and selectivity under equivalent reaction conditions.

\section{References}

[1] J. Liu, P. K. Thallapally, B. P. McGrail, D. R. Brown, J. Liu, Chem. Soc. Rev., 2012, 41, 2308-2322.

[2] Q. Chen, M. Luo, P. Hammershoj, D. Zhou, Y. Han, B. W. Laursen, C. G. Yan, B. H. Han, J. Am. Chem. Soc., 2012, 134, 6084-6087.

[3] W. J. Xue, Z. J. Li, H. L. Huang, Q. Y. Yang, D. H. Liu, Q. Xu, C. L. Zhong, Chem. Eng. Sci., 2016, 140, 1-9.

[4] J. Wang, Y. Lin, Q. Yue, K. Tao, C. Kong, L. Chen, RSC Adv., 2016, 6, 53017-53024.

[5] M. Liu, K. Gao, L. Liang, J. Sun, L. Sheng, M. Arai, Catal. Sci. Technol., 2016, 6, 6406-6416.

[6] Q. He, J. W. O'Brien, K. A. Kitselman, L. E. Tompkins, G. C. T. Curtis, F. M. Kerton, Catal. Sci. Technol, 2014, 4, 1513-1528.

[7] A. C. Kathalikkattil, R. Babu, R. K. Roshan, H. Lee, H. Kim, J. Tharun, E. Suresh, D. W. Park, J. Mater. Chem. A, 2015, 3, 22636-22647.

[8] J. Roeser, K. Kailasam, A. Thomas, ChemSusChem, 2012, 5, 1793-1799.

[9] P. Puthiaraj, S. Ravi, K. Yu, W. S. Ahn, Appl. Catal. B, 2019, 251, 195-205.

[10] M. H. Alkordi, Ł. J. Weseliński, V. D'Elia, S. Barman, A. Cadiau, M. N. Hedhili, A. J. Cairns, G. AbdulHalim, J. M. Basset, M. Eddaoudi, J. Mater. Chem. A, 2016, 4, 7453-7460.

[11] Y. M. Shen, W. L. Duan, M. Shi, Eur. J. Org. Chem., 2004, 3080-3089.

[12] J. Sun, S. Zhang, W. Cheng, J. Ren, Tetrahedron Lett., 2008, 49, 3588-3591.

[13] V. Caló, A. Nacci, A. Monopoli, A. Fanizzi, Org. Lett., 2002, 4, 2561-2563.

[14] J. M. Sun, S. Fujita, M. Arai, J. Organomet. Chem., 2005, 690, 3490-3497.

[15] J. Peng, Y. Deng, New J. Chem., 2001, 25, 639-641.

[16] H. Kawanami, A. Sasaki, K. Matsui, Y. Ikushima, Chem. Commun., 2003, 896-897.

[17] H. Yang, Y. Gu, Y. Deng, F. Shi, Chem. Commun., 2002, 274-275.

[18] F. Zhou, S. L. Xie, X. T. Gao, R. Zhang, C. H. Wang, G. Q. Yin, J. Zhou, Green Chem, 2017, 19, 3908-3915.

[19] T. Ema, Y. Miyazaki, J. Shimonishi, C. Maeda, J. Hasegawa, J. Am. Chem. Soc., 2014, 136, 15270-15279.

[20] L. Han, H. J. Choi, S. J. Choi, B. Liu, D. W. Park, Green Chem., 2011, 13, 1023-1028.

[21] L. Han, S. W. Park, D. W. Park, Energy Environ. Sci., 2009, 2, 1286-1292.

[22] X. Zhang, D. Wang, N. Zhao, A. S. N. Al-Arifi, T. Aouak, Z. A. Al-Othman, W. Wei, Y. Sun, Catal. Commun., 2009, 11, 43-46.

[23] Y. Xie, Z. Zhang, T. Jiang, J. He, B. Han, T. Wu, K. Ding, Angew. Chem. Int. Ed., 2007, 46, 7255-7258.

[24] Y. Zhang, S. Yin, S. Luo, C. T. Au, Ind. Eng. Chem. Res., 2012, 51, 3951-3957. 


\section{Graphical Abstract}

Chin. J. Catal., 2020, 41: 485-493 doi: S1872-2067(19)63487-X

Ionization of a covalent organic framework for catalyzing the cycloaddition reaction between epoxides and carbon dioxide

Yan Zhang, Hui Hu, Jia Ju, Qianqian Yan, Vasanthakumar Arumugam, Xuechao Jing *, Huaqiang Cai *, Yanan Gao

Institute of Chemical Materials, China Academy of Engineering

Physics; Hainan University; Liaocheng Luxi Polycarbonate Co. Ltd.

A two-dimensional covalent organic framework was grafted with ionic liquid and exhibited excellent catalytic performance for the chemical fixation of $\mathrm{CO}_{2}$ via reaction with epoxides under solvent free and co-catalyst free conditions.

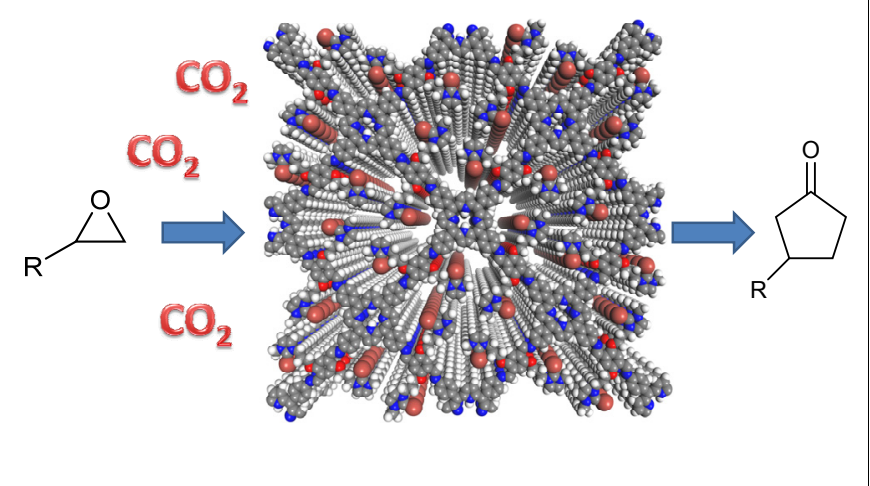

[25] W. L. Wang, C. Y. Li, L. Yan, Y. Q. Wang, M. Jiang, Y. J. Ding, ACS Catal., 2016, 6, 6091-6100.

[26] X. Zhou, Y. Zhang, X. Yang, L. Zhao, G. Wang, J. Mol. Catal. A Chem., 2012, 361, 12-16.

[27] J. Tharun, K. M. Bhin, R. Roshan, D. W. Kim, A. C. Kathalikkattil, R. Babu, H. Y. Ahn, Y. S. Won, D. W. Park, Green Chem., 2016, 18, 2479-2487.

[28] X. Feng, X. S. Ding, D. L. Jiang, Chem. Soc. Rev., 2012, 41, 6010-6022.

[29] S. Y. Ding, W. Wang, Chem. Soc. Rev., 2013, 42, 548-568.

[30] H. Hu, Q. Q. Yan, R. L. Ge, Y. A. Gao, Chin. J. Catal, 2018, 39, 1167-1179.

[31] U. Diaz, A. Corma, Coord. Chem. Rev., 2016, 311, 85-124.

[32] J. L. Segura, M. J. Mancheno, F. Zamora, Chem. Soc. Rev., 2016, 45, 5635-5671.

[33] H. Xu, X. Chen, J. Gao, J. Lin, M. Addicoat, S. Irle, D. L. Jiang, Chem. Commun., 2014, 50, 1292-1294.

[34] Y. Wu, H. Xu, X. Chen, J. Gao, D. L. Jiang, Chem. Commun., 2015, 51, 10096-10098.

[35] H. B. Aiyappa, J. Thote, D. B. Shinde, R. Banerjee, S. Kurungot, Chem. Mater., 2016, 28, 4375-4379.

[36] W. G. Leng, R. L. Ge, B. Dong, C. Wang, Y. A. Gao, RSC Adv., 2016, 6, 37403-37406.

[37] H. P. Ma, B. Liu, B. Li, L. Zhang, Y. G. Li, H. Q. Tan, H. Y. Zang, G. S. Zhu, J. Am. Chem. Soc., 2016, 138, 5897-5903.

[38] B. Dong, L. Y. Wang, S. Zhao, R. L. Ge, X. D. Song, Y. Wang, Y. A. Gao,
Chem. Commun., 2016, 52, 7082-7085.

[39] H. Hu, Q. Q. Yan, M. Wang, L. Yu, W. Pan, B. S. Wang, Y. A. Gao, Chin. J. Catal., 2018, 39, 1437-1444.

[40] N. Huang, P. Wang, M. A. Addicoat, T. Heine, D. L. Jiang, Angew. Chem. Int. Ed., 2017, 56, 4982-4986.

[41] M. Yuasa, K. Oyaizu, A. Yamaguchi, M. Kuwakado, J. Am. Chem. Soc., 2004, 126, 11128-11129.

[42] X. Chen, M. Addicoat, E. Jin, L. Zhai, H. Xu, N. Huang, Z. Guo, L. Liu, S. Irle, D. L. Jiang, J. Am. Chem. Soc., 2015, 137, 3241-3247.

[43] S. Zhao, B. Dong, R. L. Ge, C. Wang, X. D. Song, W. Ma, Y. Wang, C. Hao, X. W. Guo, Y. A. Gao, RSC Adv., 2016, 6, 38774-38781.

[44] W. G. Leng, Y. S. Peng, J. Q. Zhang, H. Lu, X. Feng, R. L. Ge, B. Dong, B. Wang, X. P. Hu, Y. A. Gao, Chem. Eur. J., 2016, 22, 9087-9091.

[45] S. Mitra, S. Kandambeth, B. P. Biswal, A. Khayum M, C. K. Choudhury, M. Mehta, G. Kaur, S. Banerjee, A. Prabhune, S. Verma, S. Roy, U. K. Kharul, R. Banerjee, J. Am. Chem. Soc., 2016, 138, 2823-2828.

[46] K. Sumida, D. L. Rogow, J. A. Mason, T. M. McDonald, E. D. Bloch, Z. R. Herm, T. Bae, J. R. Long, Chem. Rev., 2012, 112, 724-781.

[47] R. L. Paddock, Y. Hiyama, J. M. McKay, S. T. Nguyen, Tetrahedron Lett., 2004, 45, 2023-2026.

[48] R. Srivastava, D. Srinivas, P. Ratnasamy, J. Catal., 2005, 233, 1-15.

[49] W. L. Dai, L. Chen, S. F. Yin, S. L. Luo, C. T. Au, Catal. Lett., 2010, 135, 295-304.

[50] J. L. Song, Z. F. Zhang, S. Q. Hu, T. B. Wu, T. Jiang, B. X. Han, Green Chem., 2009, 11, 1031-1036.

\section{共价有机框架材料的离子化改性及其催化合成环碳酸酯的性能研究}

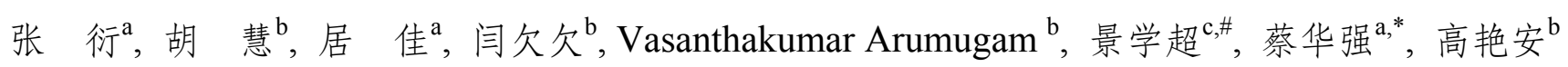
${ }^{\mathrm{a}}$ 中国工程物理研究院化工材料研究所, 四川绵阳 621900

b 海南大学热带岛屿资源先进材料教育部重点实验室, 海南海口570228

$\mathrm{c}^{\mathrm{q}}$ 聊城鲁西聚碳酸酯有限公司, 山东聊城252000

摘要: 共价有机框架 $(\mathrm{COFs})$ 材料是继金属-有机框架材料之后, 在拓扑学基础上发展起来的又一类多孔材料. 这类材料是 由轻质元素 $(\mathrm{C}, \mathrm{H}, \mathrm{O}, \mathrm{N}, \mathrm{B}, \mathrm{Si}$ 等) 通过可逆共价键连接而成的结晶性有机多孔聚合物, 具有比表面积大、骨架密度低、孔道 结构规整、可人为设计以及表面易修饰改性等特点, 自2005年首次报道以来就引起了人们的广泛关注. 经过十多年的发展, $\mathrm{COFs}$ 材料已经被广泛用于气体吸附/分离、光电、能量存储、非均相催化等研究领域. 由于材料的多孔性以及相对稳定的 特点, 近年来COFs材料作为催化剂或催化剂载体用于多相催化反应已经成为该领域的一个研究热点. 但是到目前为止, 
COFs材料的离子化改性用于异相催化相关研究还相对较少. 本文选择二维骨架中含有羟基基团的 $\mathrm{H}_{2} \mathrm{P}-\mathrm{DHPh}$ COF作为载 体, 通过两步接枝反应成功地将咪唑型离子液体引入到COF材料的孔道中; 采用红外光谱、核磁共振、粉末X射线衍射、 热失重分析等方法详细地表征了COF材料在后修饰过程中的变化. 研究发现, 1,4-二溴丁烷与 $\mathrm{N}$-甲基咪唑基团的引入占据 了部分孔道, 导致框架材料的孔径和孔容减小. 同时, 我们还将该改性后的离子型 $\mathrm{COF}$ 材料在 $\mathrm{DMSO}$ /盐酸溶液中消解, 利 用核磁共振波谱计算了离子化程度. 实验结果表明, $\mathrm{N}$-甲基咪唑的接枝率约为 $4.9 \mathrm{wt} \%$. 在既定的反应条件下, 将该离子化 的COF材料作为多相催化剂用于 $\mathrm{CO}_{2}$ 和环氧化合物之间的环加成反应. 以环氧氯丙烷作为测试底物, 发现该离子型催化剂 的催化性能与 $\mathrm{H}_{2} \mathrm{P}-\mathrm{DHPh}$ COF相比有大副度提高, 转化率达到了 $91 \%\left(120^{\circ} \mathrm{C}, 24 \mathrm{~h}, \mathrm{CO}_{2}\right.$ 压力位 $\left.1.0 \mathrm{MPa}\right)$. 在相同的条件下, 该催化剂还对其他的环氧化合物具有一定的催化效果, 其中环氧丙烷的转化率高达 $95 \%$, 且目标产物碳酸丙烯酯的选择性 为 $100 \%$. 然而, 对于大分子的环氧化合物, 转化率和产率均较低, 表明催化剂具有明显的尺寸选择性. 此外, 我们还以环氧 氯丙烷的环加成反应为例考察了催化剂的循环稳定性, 经过连续的 5 次循环, 催化剂的催化活性得到了有效保持. 我们的 研究表明COF材料作为异相催化剂用于多相催化具有潜在的应用前景. 而且, 由于离子型多孔材料具有可交换的性质, 我 们可以通过将不同功能的反离子交换到孔道中, 从而得到具有不同功能特性的多孔材料. 因此, 离子化共价有机框架材料 是一类集多孔、高比表面积、可人为设计等性质于一体的新型多孔材料, 有望应用于更加广泛的研究领域.

关键词: 共价有机框架; 离子化; 催化剂; 环加成反应

收稿日期: 2019-06-29. 接受日期: 2019-07-25. 出版日期: 2020-03-05.

*通讯联系人. 电话: (028)65726196; 电子信箱:caihuaqiang@caep.cn

\#通讯联系人. 电话: (0635)3481095; 电子信箱: jingxuechao@1xhg.com

基金来源：国家自然科学基金(21473196, 21702194); 海南大学科研启动基金(KYQD(ZR)1856).

本文的电子版全文由Elsevier出版社在ScienceDirect上出版(http://www.sciencedirect.com/science/journal/18722067). 